\title{
The Rate of Seller Correctness in Naming Batik Solo Pattern: Studied in Indonesia Online Marketplace
}

\author{
Berlian Rahmy Lidiawaty ${ }^{1}$, Mohammad Isa Irawan², Raden Venantius Hari Ginardi ${ }^{3}$ \\ Faculty of Creative Design and Digital Business, Institut Teknologi Sepuluh Nopember, Surabaya, 60111 \\ Faculty of Science and Digital Analytics, Institut Teknologi Sepuluh Nopember, Surabaya, 60111 \\ Faculty of Electical and Informatics Intelligence, Institut Teknologi Sepuluh Nopember, Surabaya, 60111 \\ berlidiawaty@gmail.com
}

Diterima: $14 / 04 / 2020$.

Direview: $21 / 04 / 2020$.

Diterbitkan: 31/08/2020.

Hak Cipta (C) 2020 oleh Penulis (dkk) dan Jurnal Sosial Humaniora (JSH)

*This work is licensed under the Creative Commons Attribution International License (CC BY 4.0). http://creativecommons.org/licenses/by/4.0/

\section{Subject Area: Marketing}

\begin{abstract}
Every pattern in batik Solo has a different meaning that affects its use. There are patterns for cultural ceremonies, including funerals. Therefore, the seller of batik Solo's product has to be able to give the right title as the name of its product in the online marketplace, so the customer will not miss wear the batik in the wrong ceremony. According to the importance of naming batik Solo's product, this study aims to assess the accuracy of batik Solo pattern naming by sellers in Indonesian online marketplace. Thus the result of it can be used by the buyer as a recommendation where is the best marketplace to purchase the batik Solo product. First, the study collects the images sample from four biggest marketplaces in Indonesia; Tokopedia, Bukalapak, Shopee and Lazada. The sample was collected by inputting the name of batik Solo pattern in the marketplace's search bar. The keywords that have been used to collect the sample are batik Parang, batik Truntum, batik Sawat, batik Kawung and batik Slobog. Those are the kinds of batik Solo pattern that has different expedience from each other. After 834 samples have been collected, the study assigns whether the seller give the correct name to the batik Solo product or not. The result of this study is the correctness percentage (CP) of the seller in naming their batik Solo product. In general, the CP is $82,13 \%$, Marketplace with the highest CP is Lazada (95,42\%) and the highest CP of pattern is Parang (91\%). Besides that, the study also rates marketplace with the parameter of Best Marketplace by Pattern (BMP) and Best Marketplace of Category (BMC). The study divided the parameters to rate marketplace because the best marketplace that has the highest correctness percentage in one category of a pattern is not always a marketplace that has the highest correctness percentage in that pattern.
\end{abstract}

Keywords: batik Solo pattern; batik product; marketplace online; seller correctness.

\section{Introduction}

Batik has long been known as Indonesia's cultural heritage, as UNESCO recognizes it as a world cultural heritage (S. Kundharu, M. Taufiq, 2014). The word batik is origin from Javanese word, "amba" and "titik". Amba means fabric and "titik" means how to draw a pattern in a fabric (U. Rizky, 2014). According to those meanings, the definition of batik is a fabric that has pattern on it. 
Several locations in Indonesia has its unique batik pattern, including Solo, central java. Based on batik location, it consists of batik keraton (palace) and batik pesisir (coastal). Batik keraton is a traditional batik when in history it was used by royal family only. Batik Solo is one type of batik keraton.

Every pattern in traditional batik, including batik Solo has symbols and spiritual value. It is usually worn as clothes or a compliment by the royal family to attend some rituals or ceremonies (P. Nimas, P. Hajar, n.d.). There are also some larangan pattern or prohibited pattern in batik Solo. It is prohibited to wear by ordinary people and only worn in some traditional ceremonies. Also, the one who wears this kind of batik has moral responsibility according to the meaning and message that want to deliver by the batik's pattern.

Batik Solo itself has several patterns. But this research has limited in five batik Solo patterns only. They are batik Parang, batik Truntum, batik Sawat, batik Kawung and batik Slobog.

Batik Parang symbolizes a noble life and authority for public society. Parang comes from a word "pereng" in Javanese that has meaning sloping riverbank and mountainside (S. Kundharu, M. Taufiq, 2014). It makes Parang pattern form like continuous diagonal S. Parang pattern is one of the prohibited pattern. Only the king and his descendants that can wear it. The bigger the S symbol in Parang pattern, the higher of someone position in the kingdom.

Batik Truntum pattern is like a flower and usually is dominated with black colour. The word Truntum comes from Javanese "tuntum" that means repetition or philosophically the entwining love from spouse (S. Kundharu, M. Taufiq, 2014). Therefore, this batik pattern usually is worn by the parents in their children wedding ceremony and in the watering ceremonial such as mitoni or the seventh month of pregnancy ceremony.

Batik Sawat is also one kind of prohibited pattern. Sawat pattern has a meaning of firmness. Its wings symbolize determination and persistence (B. Gatut, n.d.). The king and his descendants can wear this pattern. Besides that, the one who has legacy position such as governor also can wear this batik. Batik Kawung pattern symbolizes wisdom. The royal community who can wear this batik is the one with a good self-control and the one who has a clean heart without any desire of joy (P. Nimas, P. Hajar, n.d.).

Batik Slobog pattern has meaning big and loose. It is usually used to be a cover for a corpse. People who attends in funeral ceremony also can wear this batik (S. Nian, 1990).

When batik was only worn by royal family in history, by the time everyone can wear batik nowadays. Batik from traditional art and instrument can settle with contemporary situations and maintain tradition (H. Kalinggo, n.d.). Therefore, both traditional and modern batik compete to sell batik in Indonesia or overseas based on the increasing demand of batik (N. Prihadi, n.d.).

With the rapid development of information and internet technology, the batik industry can trade and sell the batik Solo product using e-commerce. Since 2018, the Indonesian government also encourage small-medium enterprises (SME) in Indonesia to utilize marketplace online (A.R.T. Putri, Y. Priyandari, 2019).

In the marketplace online, all of batik Solo seller can promote their product. The sellers usually upload the image of their product in marketplace website and give title of their product based on the name 
of batik Solo pattern. Therefore, this research aims to rate the seller correctness in naming batik Solo's product in four marketplaces online in Indonesia: Tokopedia, Bukalapak, Shopee and Lazada.

Because of the importance of batik Solo's pattern meanings, how correct the seller in naming batik Solo product is really crucial. Since the customer can buy the miss naming batik product, they also can misswear it in the wrong event or ceremony.

\section{Method}

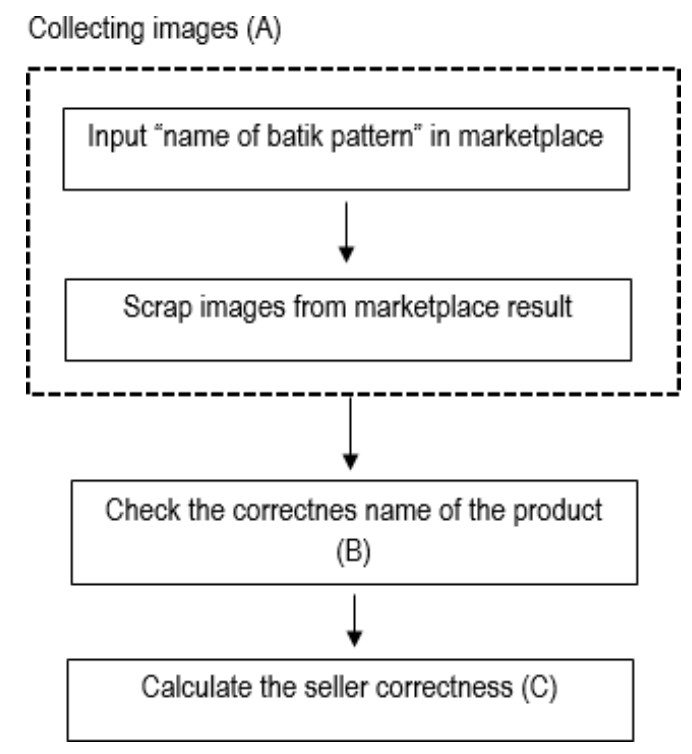

Figure 1. General step of research's method

This research needs to collect the images of batik Solo based on its pattern name in four marketplaces online in Indonesia. After that, the research will check and calculate the rate of the seller correctness in naming batik Solo products. For more details about the method in this research can be seen in Figure 1.

There are three main steps as the method of this research as shown in Figure 1. The first step or step A is collecting the images from marketplaces that will explain more details in section Collecting Images. The second step or step B is checking the correctness name of batik Solo's product that will be explained more details in section Checking the Correctness Name of Product. The last step or step C is calculating the seller correctness that will be explained more in section Calculating the Seller Correctness. After calculating the seller correctness in naming batik Solo's product, the research also shows the best marketplace's seller with the highest value of seller correctness in percentage (\%).

\section{Collecting Images}

Every marketplace online, especially in Indonesia including Tokopedia, Bukalapak, Shopee, and Lazada already provided with a search bar to facilitate the users looking for items they want to purchase. When collecting images of batik Solo's product, the first step is inputting the batik Solo's pattern name as a keyword in the marketplace. The keyword that has been input to the search bar in marketplace are; "Batik Parang", "Batik Truntum", "Batik Sawat", "Batik Kawung", and "Batik Slobog”. These keywords have been used to collect image from the marketplaces in this research. 
After the marketplace showing image result from each keyword, then the research continues to scrap and collect images from marketplace search results. The research only collect images that appeared in the first page of marketplace search result as a sample. Every marketplace has a different number of maximum images that can appear in the first page of search results. Tokopedia shows 60 results, Bukalapak shows 50 results, Shopee shows 50 results and Lazada shows 40 results. The total images from one pattern in one marketplace can be less than the number that mentioned before when the results that appear in the marketplace are measly.

\section{Checking The Correctness Name of Product}

The second step in this method is checking the correctness name of the product based on the keywords input. The correctness name of the product is obtained by comparing the keyword that is used to get the image from marketplaces with the image from marketplace's search result. It needs to manually check if the image contains one of batik Solo's pattern or not.

For example, if the keyword that used in the marketplaces is "Batik Parang", then it needs to observe more closely to the image result whether the image really has batik Parang pattern on it or not. If the image that represents a product of a seller really consists of Parang pattern, then the image product will be marked as TR or True Result. Otherwise, if the image doesn't consist of Parang pattern but it appears in the marketplace search result, it will be marked as FR or False Result.

The research does a check and mark step to all of the images from search result in marketplaces of Tokopedia, Bukalapak, Shopee, and Lazada. This step also has been implemented in Truntum pattern, Sawat pattern, Kawung pattern, and Slobog pattern.

\section{Calculating the Seller Correctness}

In the method in section B before, it explains that this research collects the total amount of image that labeled with TR and image that is labeled with FR. The outcome of this research is CP or Correctness Percentage. The formula to get $\mathrm{CP}$ is shown in formula 1 below.

$C P=\frac{\sum T R}{\sum T R+\sum \quad R} \times 100 \%$

TR $=$ True Result,

$\mathrm{FR}=$ False Result

$\mathrm{CP}=$ correctness percentage .

The $\mathrm{CP}$ is calculating in specific use. At first, the $\mathrm{CP}$ will calculate in general which means the $\mathrm{CP}$ from all of the images found from all of the patterns and from all of the marketplaces. The next step is calculating CP from every marketplace and the CP from every pattern. It also records the categories that are found in every pattern and which marketplace has the highest CP in every category.

When checking the CP in every pattern, this research uses the variable of BMP (Best Marketplace by Pattern) to rate marketplace that has highest $\mathrm{CP}$ in a pattern. There is also a variable of $\mathrm{BMC}$ (Best Marketplace by Category) to rate the marketplaces that have the highest $\mathrm{CP}$ based on a category in a pattern. 
This research also tries to look for one or some reasons why one marketplace is good at naming batik Solo, and why the others not. It also rates the seller correctness in every pattern to determine which pattern that the seller know best, and which pattern that the seller wrong in naming their product based on batik Solo's pattern.

\section{Results and Discussions}

From the step of collecting images, 834 images have been fetched up. These images have been collected from four marketplaces and five patterns as shown in Table 1. There are some categories found from all of the images, such as men clothes, women clothes, fabric, and other categories.

The result in Table 1 has been collected since November 2019. The result after that time can be changed anytime. The calculating in this paper also based on the data that collected in that time. The calculating can show different results if it is done from the samples in different times.

Table 1. The amount of Images

\begin{tabular}{lrrrrr}
\hline \multirow{2}{*}{ Pattern } & \multicolumn{4}{c}{ Marketplace Online } & \multirow{2}{*}{ Total } \\
& Tokopedia & Bukalapak & Shopee & Lazada & \\
\hline Parang & 60 & 50 & 50 & 40 & $\mathbf{2 0 0}$ \\
\hline Truntum & 60 & 50 & 50 & 33 & $\mathbf{1 9 3}$ \\
\hline Sawat & 52 & 30 & 32 & 8 & $\mathbf{1 2 2}$ \\
\hline Kawung & 60 & 50 & 50 & 40 & $\mathbf{2 0 0}$ \\
\hline Slobog & 44 & 30 & 35 & 10 & $\mathbf{1 1 9}$ \\
\hline Total & $\mathbf{2 7 6}$ & $\mathbf{2 1 0}$ & $\mathbf{2 1 7}$ & $\mathbf{1 3 1}$ & $\mathbf{8 3 4}$ \\
\hline
\end{tabular}

The next step after collecting images is checking the correctness name of the product fromimages in Table 1. The research continues to calculate the correctness percentage (CP). Once the $\mathrm{CP}$ is found by calculating the total of the true result (TR) and the false result (FR), it will give information on the rate of seller correctness in naming their batik Solo's product.

In general, the value of $\mathrm{CP}$ from all of the images found is $82,13 \%$. Every marketplace has a different number of $\mathrm{CP}$. There are two marketplaces that have number of $\mathrm{CP}$ above the general correctness percentage (GCP) and two marketplaces that have number of CP below the GCP. More details information can be seen in Table 2. The marketplaces data in Table 2 is ordered by the highest $\mathrm{CP}$ to the lowest CP.

Table 2 shows that the best marketplace with the highest $\mathrm{CP}$ is Lazada. It means that the sellers of batik Solo's product there have good awareness to give the product based on the batik pattern names. Besides Lazada, Tokopedia has a good result with CP value 84,78\%. Its CP is still higher than the GCP. Meanwhile, Bukalapak and Shopee have a CP value under the GCP.

There is one factor that can explain why sellers in Lazada can reach a great $\mathrm{CP}$ in naming batik Solo's product compared with other marketplaces. The business model of Lazada is Business to 
Table 2. The Rate of Marketplace CP

\begin{tabular}{|c|c|c|}
\hline Marketplace & $\mathbf{C P}$ & Explanation \\
\hline \multirow{3}{*}{ Lazada } & \multirow{3}{*}{$95,42 \%$} & Above the GCP value \\
\hline & & Limited categories \\
\hline & & Limited samples \\
\hline \multirow{3}{*}{ Tokopedia } & \multirow{3}{*}{$84,78 \%$} & Above the GCP value \\
\hline & & Many categories \\
\hline & & The most total samples \\
\hline \multirow{3}{*}{ Bukalapak } & \multirow{3}{*}{$78,57 \%$} & Below the GCP value \\
\hline & & Many categories \\
\hline & & $\begin{array}{l}\text { Have unique categories that didn't appear in another } \\
\text { Marketplace }\end{array}$ \\
\hline \multirow[b]{2}{*}{ Shopee } & \multirow[b]{2}{*}{$74,19 \%$} & Below the GCP value \\
\hline & & $\begin{array}{l}\text { Best marketplace in couple clothes category in almost } \\
\text { all of batik pattern }\end{array}$ \\
\hline
\end{tabular}

In $\mathrm{B} 2 \mathrm{C}$, that means Lazada, only a verified seller can promote their product. Lazada has a tight contract for a business to become its seller. It means not everyone or every business can be a seller there. Lazada needs to approve and give permission first to a business before it can promote and sell something in Lazada.

Tokopedia, Bukalapak, and Shopee are marketplaces with C2C business model. In C2C business model has a different policy for the sellers. Everyone or every business can be a seller and promote their product as long they have an account in one or more of those marketplaces.

The main difference between $\mathrm{B} 2 \mathrm{C}$ and $\mathrm{C} 2 \mathrm{C}$ that's mentioned before explain how Lazada's seller can get a high number of CP in naming batik Solo's product based on its pattern. In Lazada, when only the verified seller can sell their product, they usually have selected their product at the beginning. When in Tokopedia, Bukalapak, and Shopee every seller can give a name in batik Solo's product carelessly as long as they can sell and promote their product.

The researcher then observed more to the $\mathrm{CP}$ value of every marketplace. After comparing the $\mathrm{CP}$ result, Tokopedia is the best marketplace among the other marketplace with $\mathrm{C} 2 \mathrm{C}$ business model. It means even there are a lot of sellers in Tokopedia, they have a good awareness of naming batik Solo's product based on its pattern. The CP value of Tokopedia is higher than the GCP of batik Solo pattern. In fact, only Lazada and Tokopedia that have CP above the GCP value, when Bukalapak and Shopee have CP below the GCP value.

The limited sellers that Lazada has given impact not only to the $\mathrm{CP}$ value, but also to the category that can be found in Lazada. Lazada has a very limited category in every pattern of batik Solo. Shopee as one of $\mathrm{C} 2 \mathrm{C}$ business model has limited category too even though it still has more categories than Lazada 
has. However, Shopee has good CP in the couple clothes in almost all patterns compared with the other marketplaces. The explanation about the category distribution and how is the seller CP in each pattern will be described more detail in sub-sections.

\section{Parang}

From 200 images collected in Parang pattern, the value of GCP (General Correctness Percentage) is 91\%. The BMP (Best Marketplace by Pattern) of Parang pattern is Lazada with the value of CP is 97,5\%. It is higher than GCP in Parang pattern. The other CP results from other marketplaces can be seen in Table 3.

Table 3. The CP of Marketplace in Parang Pattern

\begin{tabular}{lcc}
\hline \multicolumn{1}{c}{ Marketplace } & CP & Error \\
\hline Lazada (BMP) & $97,50 \%$ & $2,50 \%$ \\
\hline Tokopedia & $91,67 \%$ & $8,33 \%$ \\
\hline Shopee & $90,00 \%$ & $10,00 \%$ \\
\hline Bukalapak & $86,00 \%$ & $14,00 \%$ \\
\hline
\end{tabular}

From 40 image samples of the Parang pattern in Lazada, 97,5\% is really a product with Parang pattern on it. Lazada becomes the BMP (Best marketplace by Pattern) of Parang pattern with the value of error only 2,5\%. Only Lazada and Tokopedia that have a CP value higher than GCP value of Parang pattern. Shopee and Bukalapak have CP value lower than GCP value of Parang pattern. But, it will show a different number when the $\mathrm{CP}$ is rated by category or looking for the BMC (Best Marketplace by Category). In Parang pattern, there are some categories that have been found. The details are shown in Table 4.

Table 4. The BMC in Parang Pattern

\begin{tabular}{lclc}
\hline \multicolumn{1}{c}{ Category } & CP & BMC & CP \\
\hline Men clothes & $87,50 \%$ & Tokopedia & $100 \%$ \\
\hline Women clothes & $88,33 \%$ & Bukalapak & $90,91 \%$ \\
\hline Fabric & $98,39 \%$ & $\begin{array}{l}\text { Tokopedia, Shopee and } \\
\text { Lazada }\end{array}$ & $100 \%$ \\
\hline Couple clothes & $84,62 \%$ & Shopee & $100 \%$ \\
\hline
\end{tabular}

There are more categories found when collecting image of every pattern from four marketplaces. However, this result only shows the most often categories found. A category needs to fulfill at least $10 \%$ of the total samples in pattern to be recorded.

Those 4 categories in Table 4 are the most recent category that appear when "batik Parang" is inputted in marketplace search bar. Those categories dominate the search result of Parang pattern. Other categories that cannot be recorded in Table 4 have small amount of samples.

Men clothes that is found in four marketplaces has a $\mathrm{CP}$ value of $87,5 \%$ when the best marketplace to find men clothes (BMC) is in Tokopedia with a CP value of $100 \%$. It means that in 
Tokopedia, all of men clothes that entitle "batik Parang" really have Parang pattern on it.

The sellers in four marketplaces have the highest $\mathrm{CP}$ in fabric category with the BMC is Shopee and Lazada. Both Shopee and Lazada reach $100 \%$ CP value. Fabric category also has CP higher than GCP of Parang pattern. In women clothes category, the BMC is Bukalapak. While in the couple clothes, sellers in Shopee give the right name on their products. All of couple clothes in Shopee marketplace really have Parang pattern on it.

Even though Lazada is the BMP in Parang pattern, Lazada only becomes the BMC in fabric category. It means that in Parang pattern, the marketplace that becomes BMP does not always become BMC in all of category.

\section{Truntum}

After inputting the keyword of "batik Truntum" in marketplaces' search bar, there are 193 images of batik Solo's products with Truntum pattern collected. From all of the marketplaces, Truntum pattern has the GCP value of $80,83 \%$. It is lower than GCP of Parang pattern. The marketplace's CP of Truntum pattern based on four marketplaces is shown in Table 5.

Table 5. The CP of Marketplace in Truntum Pattern

\begin{tabular}{lcc}
\hline \multicolumn{1}{c}{ Marketplace } & $\mathbf{C P}$ & Error \\
\hline Lazada (BMP) & $100 \%$ & $0 \%$ \\
\hline Tokopedia & $88,33 \%$ & $11,67 \%$ \\
\hline Bukalapak & $72,00 \%$ & $28,00 \%$ \\
\hline Shopee & $68,00 \%$ & $32,00 \%$ \\
\hline
\end{tabular}

The BMP of Truntum pattern is Lazada with the CP value 100\%. It means that all of batik Solo's products entitled Truntum pattern in Lazada really have Truntum pattern on it. Only Lazada and Tokopedia have CP value above the GCP value.

The category found in Truntum pattern is more various than category found in Parang pattern. Five categories dominate the marketplace search result while there are only four categories found in Parang pattern. The best marketplaces by category (BMC) in Truntum pattern are shown in Table 6 .

Table 6. The BMC in Truntum Pattern

\begin{tabular}{lclc}
\hline \multicolumn{1}{c}{ Category } & CP & BMC & CP \\
\hline Men clothes & $80,77 \%$ & Shopee & $100 \%$ \\
\hline Women clothes & $72,73 \%$ & $\begin{array}{l}\text { Tokopedia and } \\
\text { Lazada }\end{array}$ & $100 \%$ \\
\hline Fabric & & Lazada & $100 \%$ \\
\hline & $92,54 \%$ & & \\
\hline Couple clothes & $52,94 \%$ & Shopee & $66,67 \%$ \\
\hline Cultural instrument & $100 \%$ & Bukalapak & $100 \%$ \\
\hline
\end{tabular}

The category that has CP value above the GCP value is the fabric with CP value $92,54 \%$ and 
cultural instrument with CP value 100\%. The three other categories have CP value below the GCP.

The cultural instrument is the unique category that is only found in Truntum pattern. Bukalapak is the only marketplace that has enough samples (at least $10 \%$ of pattern samples). The product that is included in cultural instruments such as blangkon or a traditional Javanese headdress worn by men and made of batik fabric.

Similar to the result of Parang pattern, Lazada is the BMP in Truntum patern, but it only becomes $\mathrm{BMC}$ in the fabric category. Other categories best found in other marketplaces.

The BMC of men clothes category in Truntum pattern is Shopee with $100 \%$ CP value. Although men's clothes category CP value is below the GCP of Truntum pattern, but Shopee's CP value reach $100 \%$.

The BMC of women clothes category is both Tokopedia and Shopee and the last, the BMC of couple clothes is Shopee. It is a different case with the men clothes category. Although this category CP value is below the GCP of Truntum pattern, both Tokopedia and Shopee CP values reach 100\%. It can be assumed that the seller errors in naming batik Truntum in men and women clothes category comes from non-BMC marketplace.

\section{Sawat}

Image samples collected from Sawat pattern is the fewest samples compared with Parang and Truntum patterns. There are only 122 images of batik Solo's product that entitle "batik Sawat". The GCP of Sawat pattern is $79,51 \%$ from all of marketplaces. Table 7 shows the rate of marketplace based on its CP in Truntum pattern. When Lazada becomes the BMP in the Parang and Truntum pattern, sample from Lazada can't be recorded in Table 7, because the samples are deficient. Lazada only has 8 samples that less than $10 \%$ of total samples of Sawat pattern result. At least, from 122 images result, a marketplace need to show minimum 13 images result, so it can be calculated its CP. Therefore, Bukalapak becomes BMP of Sawat pattern.

Table 7. The CP of Marketplace in Sawat Pattern

\begin{tabular}{lcc}
\hline \multicolumn{1}{c}{ Marketplace } & CP & Error \\
\hline Bukalapak (BMP) & $86,67 \%$ & $13,33 \%$ \\
\hline Tokopedia & $82,69 \%$ & $17,31 \%$ \\
\hline Shopee & $62,50 \%$ & $37,50 \%$ \\
\hline
\end{tabular}

Besides Bukalapak, Tokopedia with CP value 82,69\%, has CP value above the GCP value of Sawat pattern. While Shopee with only $62,5 \%$ of CP value, its number is below the GCP value of Sawat pattern. The category that was appeared in Sawat pattern also the fewest compared to Parang and Truntum. It is only 3 categories recorded. They are men clothes, women clothes and fabric. More data about it is shown in Table 8 .

Bukalapak almost becomes the BMP and BMC in all of category that's found in Sawat pattern batik Solo's product if it becomes the BMC in all of three categories. Unfortunately, the BMC of women clothes category is not Bukalapak, but Tokopedia. Meanwhile, the best category with the highest CP or the less error made by the sellers is fabric. It has $95,59 \% \mathrm{CP}$ value. Men clothes and women clothes have 
Table 8. The BMC in Sawat Pattern

\begin{tabular}{lclc}
\hline \multicolumn{1}{c}{ Category } & CP & BMC & CP \\
\hline Men clothes & $67,86 \%$ & Bukalapak & $75,00 \%$ \\
\hline Women clothes & $50,00 \%$ & Tokopedia & $71,43 \%$ \\
\hline Fabric & $95,59 \%$ & $\begin{array}{l}\text { Bukalapak and } \\
\text { Shopee }\end{array}$ & $100 \%$ \\
\hline
\end{tabular}

\section{Kawung}

Batik Kawung samples has the same number of batik Parang samples. There are 200 image of batik product that entitled "batik Kawung" from Tokopedia, Bukalapak, Shopee and Lazada. It means, all of marketplace show the maximum number of samples in first page of search results.

The GCP value of batik Kawung is $86 \%$. It makes Kawung becomes number two pattern that the sellers made less error in naming batik Solo's product, below Parang pattern. The CP values from all marketplace can be seen in Table 9. Same as Sawat pattern, Bukalapak becomes the BMP in Kawung pattern. Bukalapak, Tokopedia and Lazada have CP value higher than the GCP of batik Kawung pattern. Meanwhile, Shopee with $79 \%$ of CP, have CP value lower than the general CP of batik Kawung pattern.

Table 9. The CP of Marketplace in Kawung Pattern

\begin{tabular}{lcc}
\hline \multicolumn{1}{c}{ Marketplace } & CP & Error \\
\hline Bukalapak (BMP) & $90,00 \%$ & $10,00 \%$ \\
\hline Tokopedia & $88,33 \%$ & $11,67 \%$ \\
\hline Lazada & $87,50 \%$ & $12,50 \%$ \\
\hline Shopee & $78,00 \%$ & $22,00 \%$ \\
\hline
\end{tabular}

When in Truntum pattern Bukalapak becomes the only marketplace that fulfills the cultural instrument category minimum samples, in Kawung pattern Bukalapak also becomes the only marketplace that fulfils worship tool category samples. Items that are included in worship tool such as sarong or a large tube or length of fabric often wrapped around the waist used by men muslim to pray, mukena or women clothes for praying, and sajada or prayer rug. This data can be seen in Table 10. It makes Bukalapak becomes the marketplace that have more various category than the other marketplaces.

Table 10. The BMC in Kawung Pattern

\begin{tabular}{lclc}
\hline \multicolumn{1}{c}{ Category } & CP & BMC & CP \\
\hline Men clothes & $62,86 \%$ & Tokopedia & $78,57 \%$ \\
\hline Women clothes & $80,00 \%$ & Shopee & $93,75 \%$ \\
\hline Fabric & $96,51 \%$ & $\begin{array}{l}\text { Bukalapak and } \\
\text { Shopee }\end{array}$ & $100 \%$ \\
\hline Couple clothes & $72,73 \%$ & Shopee & $70,00 \%$ \\
\hline
\end{tabular}


As the result in other patterns before, the result in Kawung pattern also gives information that the marketplace that becomes BMP is not always becomes the BMC in all of category in a pattern. Bukalapak is the BMP of batik Kawung pattern, but it only becomes BMC in fabric and worship tool categories. Once again, shopee becomes the BMC in couple clothes category. In batik Kawung pattern, Shopee also becomes BMC in women clothes category.

From five categories that are found in batik Kawung pattern, only two categories that have CP value above the GCP value. First category is fabric with $96,51 \%$ and the BMC of it is Bukalapak and Shopee. Another category is worship tools with $87,5 \%$ CP value. The BMC of worship category in Kawung pattern is Bukalapak, but the CP value is only 83,33\% which is under the Kawung GCP value. It means that worship tool appears in other marketplace search result, but the number does not fullfill the minimum samples. Therefore, Bukalapak that has more sample becomes the BMC of worship tool in Kawung pattern.

On the other hand, women clothes CP only reaches $80 \%$ with Shopee as the BMC. But, Shopee's CP value in this category is $93,75 \%$ which is higher than the GCP in Kawung pattern. It indicates that there are some sellers from other marketplaces who give the wrong name of women clothes product with batik Kawung, but actually it doesn't have Kawung pattern on its product.

\section{Slobog}

The number of samples of Slobog pattern have similarity with Sawat pattern, where the samples are limited. The total image in Slobog patten is the less than other patterns that belonging to this research. It only shows 119 images results. The samples from Lazada also do not reach 10\% of total samples in Slobog pattern. That is why in Table 11, Lazada CP value cannot be recorded.

Slobog pattern is a pattern that has the lowest GCP compared to other pattern. The GCP value of Slobog pattern only reaches $65,55 \%$. It means that only 78 images of batik Solo's product from all of marketplace that really have Slobog pattern on it. The other images result do not have Slobog pattern element in those product.

Table 11. The CP of Marketplace in Slobog Pattern

\begin{tabular}{lcc}
\hline \multicolumn{1}{c}{ Marketplace } & CP & Error \\
\hline Tokopedia (BMP) & $68,18 \%$ & $31,82 \%$ \\
\hline Shopee & $65,71 \%$ & $34,29 \%$ \\
\hline Bukalapak & $50,00 \%$ & $50,00 \%$ \\
\hline
\end{tabular}

Different from the other patterns, in Slobog pattern the best marketplace by the pattern or the BMP is Tokopedia. Tokopedia's CP value is $68,18 \%$, which is higher than the GCP value of Slobog pattern. Shopee with CP value $65,71 \%$ also has CP value higher than the GCP. Meanwhile Bukalapak only has $50 \%$ CP value, which is lower than the GCP value of Slobog pattern.

Because of the limited samples of image in Slobog pattern, the category that appears in 

marketplace search result is limited too. Like Sawat pattern, there are only three categories that dominate in all of marketplace search result. These categories with its BMC can be seen in Table 12.

Table 12. The BMC in Slobog Pattern

\begin{tabular}{lclc}
\hline \multicolumn{1}{c}{ Category } & CP & BMC & CP \\
\hline Women clothes & $91,67 \%$ & $\begin{array}{l}\text { Tokopedia and } \\
\text { Bukalapak }\end{array}$ & $100 \%$ \\
& & Tokopedia & $57,58 \%$ \\
\hline Fabric & $41,76 \%$ & Bukalapak & $100 \%$ \\
\hline
\end{tabular}

From all of pattern, marketplace that becomes BMP does not always become BMC in that pattern. The same result shows in Slobog pattern. Tokopedia becomes the BMP in this pattern, but Tokopedia does not become BMC of worship tool category. While in the women clothes and fabric categories, Tokopedia becomes its BMC. Even though in women clothes category, Tokopedia becomes the BMC with Bukalapak.

The category that has $\mathrm{CP}$ value higher than GCP value is women clothes and worship tool. Women clothes have CP value $91,67 \%$ and worship tool CP value is $100 \%$. The CP value of fabric in Slobog pattern also has the lowest $\mathrm{CP}$ of all category in all of pattern. The CP only reaches $41,67 \%$. It means that the sellers from all of marketplace have high error rate in naming fabric product that have Slobog pattern. They entitled their product with "batik Slobog", but in reality it doesn't have Slobog pattern.

Shopee does not become the BMC in any categoy. Even though in the rate of BMP, Shopee CP value $(65,71 \%)$ landed in second position above Bukalapak. Meanwhile Bukalapak becomes the BMC in the women clothes and worship tool categories although its total CP value is below the GCP of Slobog patterns. From all of patterns in this research, Shopee also never becomes the BMP of any pattern.

Nevertheless, Shopee is good at couple clothes category that always becomes the BMC in Parang pattern, Truntum pattern, and Kawung pattern. Shopee also becomes BMC in some categories. Shopee never becomes BMP in any pattern probably caused by its general $\mathrm{CP}$ value rank that is the lowest compared with other marketplaces.

After documenting all pattern from four marketplaces, this research also makes a list of the rate of sellers' correctness based on batik Solo pattern. This data is explained in Table 13. This data ordered by the pattern with the highest $\mathrm{CP}$ value to the lowest $\mathrm{CP}$ value.

Table 13. The CP of Batik Solo's Pattern

\begin{tabular}{lcc}
\hline Pattern & CP & Error \\
\hline Parang & $91,00 \%$ & $9,00 \%$ \\
\hline Kawung & $86,00 \%$ & $14,00 \%$ \\
\hline Truntum & $80,83 \%$ & $19,17 \%$ \\
\hline Sawat & $79,51 \%$ & $20,49 \%$ \\
\hline Slobog & $65,55 \%$ & $34,45 \%$ \\
\hline
\end{tabular}

Table 13 gives information about which pattern that the sellers have good rate of correctness in naming their product with the name of batik Solo's pattern and which pattern have the lowest awareness by 
the sellers. Thus this data can be used as the recommendation which pattern is best to purchase in online marketplaces in Indonesia.

From Table 13, it can be concluded that the sellers in four marketplaces have a great awareness in Parang pattern. It is proven by the CP value of Parang pattern is $91 \%$. While the lowest CP is Slobog pattern with only have $65,55 \% \mathrm{CP}$ value.

As known before, the GCP value of all pattern is $82,13 \%$. Therefore, from five patterns, there are only two patterns that has CP value above the GCP value. They are Parang pattern which is the highest rate with CP value $91 \%$ and Kawung pattern with CP value $86 \%$. Other pattern including Truntum, Sawat and Slobog have CP value below the GCP value. Truntum only has $80,83 \%$ CP value, Sawat only has $79,51 \%$ $\mathrm{CP}$ value and Slobog, the least, only has $65,55 \% \mathrm{CP}$ value.

There is main reason why the sellers have a low CP in naming batik Solo's product with Slobog pattern. From the history that mentioned in introduction, Slobog is only used in funeral ceremony. It is different from other patterns that are often worn by royal family and royal community. This reason might make the sellers or the people don't really notice about this pattern.

\section{Conclusion}

Overall the rate of sellers correctness in naming batik Solo's product in four online marketplaces in Indonesia is pretty good with correctness percentage (CP) in general $82,13 \%$. The best marketplace in naming batik Solo's product in general is Lazada with CP value $95,42 \%$. The best pattern that the sellers in marketplace have the best awareness in naming batik Solo's product is Parang with CP value 91\%. In every pattern, there is one best marketplace by the pattern (BMP). But, the marketplace that becomes BMP in a pattern does not always become the best marketplace by category (BMC). In Parang pattern, the BMP is Lazada with four categories found, there are men clothes with Tokopedia as the BMC, women clothes with Bukalapak as the BMC, fabric with Shopee and Lazada as the BMC, and couple clothes with Shopee as the BMC. In Truntum pattern the BMP is Lazada with five categories found, they are men clothes with Shopee as the BMC, women clothes with Tokopedia and Shopee as the BMC, fabric with Lazada as the BMC, couple clothes with Shopee as the BMC and cultural instrument with Bukalapak as the BMC. In Sawat pattern the BMP is Bukalapak with three categories found, they are men clothes with Bukalapak as the BMC, women clothes with Tokopedia as the BMC, and fabric with Bukalapak and Shopee as the BMC. In Kawung pattern, Bukalapak is the BMP with five categories found, they are men clothes with Tokopedia as the BMC, women clothes with Bukalapak as the BMC, fabric with Bukalapak and Shopee as the BMC, couple clothes with Shopee as the BMC and worship tool with Bukalapak as the BMC. In Slobog pattern, Tokopedia is the BMP with three categories found, they are women clothes with Tokopedia and Bukalapak as the BMC, fabric with Tokopedia as the BMC, and worship tool with Bukalapak as the BMC.

\section{References}

A.R.T. Putri, Y. Priyandari, E. L. (2019). Design of e-commerce competency Improvement program for batik SMEs in Surakarta. IOP Conference Series: Materials Science and Engineering, vol 598.

B. Gatut, V. A. (n.d.). Batik industry of Indonesia: the rise, fall and prospects. In Studies in Business and Economics: Vol. 5(3). Lucian Blaga University of Sibiu, Faculty of Economic Sciences. 
H. Kalinggo. (n.d.). Bathik sebagai busana dalam tatanan dan tuntunan. Yayasan Peduli Keraton Surakarta Hadiningrat.

N. Prihadi. (n.d.). A socio-cultural dimension of local batik industry development in Indonesia. The 23rd Pacific Conference of the Regional Science Association International (RSAI) and the 4th Indonesian Regional Science Association (IRSA) Institute.

P. Nimas, P. Hajar, G. A. (n.d.). Local wisdom values in Kawung batik and its relevance to moral education. 2nd International Conference on Art and Arts Education (ICAAE), vol 327.

S. Kundharu, M. Taufiq, W. S. (2014). The study of philosophical meaning of batik and kimono motifs to foster collaborative creative industry. Asian Social Science, $x$ (April), 52-63.

S. Nian, D. (1990). Batik dan mitra = batik and its kind. Djambatan.

U. Rizky. (2014). Ensiklopedia batik dan kain hias nusantara. CV. Angkasa. 